\title{
Pharmaciana
}

Vol.9, No.2, Nov 2019, Page. 201-210

ISSN: 2088 4559; e-ISSN: 24770256

DOI: $10.12928 /$ pharmaciana.v9i2.14070

\section{Real-Time PCR-based detection of bovine DNA by specific targeting on cytochrome-B}

\author{
Nina Salamah ${ }^{1,4}$, Yuny Erwanto ${ }^{2,3}$, Sudibyo Martono ${ }^{1}$, Abdul Rohman*1,3 \\ ${ }^{1}$ Department of Pharmaceutical Chemistry, Faculty of Pharmacy, Universitas Gadjah Mada \\ ${ }^{2}$ Division of Animal Products Technology, Faculty of Animal Science, Universitas Gadjah Mada \\ ${ }^{3}$ Research Centre of Halal Products, Universitas Gadjah Mada \\ ${ }^{4}$ Department of Analytical Chemistry, Faculty of Pharmacy, Universitas Ahmad Dahlan
}

Submitted: 10-09-2019

Reviewed: 02-11-2019

Accepted: 29-11-2019

\begin{abstract}
The design of specific primers is an interesting research topic such that it offers selective, specific, and effective DNA analysis using real-time PCR. This research was intended to detect bovine DNA using real-time PCR and specific primers to ensure the halal authenticity of food products. Primers of bovine DNA sequences were designed in the NCBI and Primer-BLAST programs. The outcome validation was assessed using several parameters, namely specificity, repeatability, and linearity by real-time PCR. Primer specificity test was performed on fresh tissue (pork and negative control), while the repeatability test used six replications and was based on the calculated coefficient of variation $(\mathrm{CV})$. In the linearity test, six different DNA concentrations $(50000,10000,5000,500$, 100 , and $50 \mathrm{pg} / \mu \mathrm{L}$ ) were examined to obtain the efficiency value. Using the specific primer from Cytochrome-B, the real-time PCR could specifically identify the presence of bovine DNA at the optimum annealing temperature of $58.7^{\circ} \mathrm{C}$. The repeatability analysis yielded a coefficient of variation $(\mathrm{CV})$ of $0.57 \%$, while the linearity test produced an efficiency value of $206 \%$. These figures confirm that the method employed in this study is not only specific but also sensitive and reliable for detecting bovine DNA. Real-time PCR using specific primer targeting on the cytochromeB region of bovine DNA (forward: CTACTGACACTCACATGAATTGG; reverse CACTAGGATGAGGAGAAAGTATAGG) can be used to identify bovine DNA and distinguish it from porcine DNA.
\end{abstract}

Keywords: primer, Cytochrome-B, bovine DNA, specific, real-time PCR

\footnotetext{
*Corresponding author:

Abdul Rohman

Department of Pharmaceutical Chemistry, Faculty of Pharmacy, Universitas Gadjah Mada

Research Centre of Halal Products, Universitas Gadjah Mada

Email: abdulkimfar@gmail.com
} 


\section{INTRODUCTION}

For Muslims, food products are not safe without halal status. It follows a belief that halal is the highest quality of food products and that it already includes food safety. Researchers continuously seek or develop analytical methods that can detect and even quantify the presence of non-halal components in food products. More importantly, this attempt answers the necessity of feeling assured that foodstuffs are derived from halal materials, one of which is raw products from cattle.

The identification of meat in food products has lately adopted DNA-based analytical methods. Aside from their fast and specific procedure, these methods rely on DNA that is advantageously more stable even though it has been exposed to physical and chemical processing (Iwobi et al., 2012). Accordingly, this research seeks a valid and reliable analytical method to detect the presence of beef gelatin through specific primers from edible composition to ensure the halal authenticity of pharmaceutical products.

Compared to a conventional polymerase chain reaction (PCR), real-time PCR provides a more sensitive, simpler, and faster analysis. It is the development of the PCR method that allows the results of amplification to be directly observed and analyzed quantitatively using DNA dyes and fluorescent trackers (Sudjadi, 2008). Another use of real-time PCR is for the detection of single nucleotide polymorphisms and accurate determination of melting temperature from the resultant real-time PCR curves. Its development extends to molecular biology, especially for halal analysis. An example includes the detection of pork in consumables (Himawati, 2013; Martin et al., 2009; Soares et al., 2013; Taufiq, 2014). In general, real-time PCR analysis is divided into three parts, namely the exponential phase, the linear phase, and the flat phase. In the exponential phase, it is possible to obtain PCR amplification products with efficiencies close to $100 \%$, which means DNA duplication occurs in this phase. The percentage of efficiency depends on PCR conditions, the characteristics of the designed primers, the purity of the DNA print, and the length of the amplification product. PCR results can be analyzed by correlating $\mathrm{Cq}(\mathrm{Ct})$ values with DNA concentration. A better correlation is obtained by relating $\mathrm{Cq}$ number with the logarithm-transformed concentration because it yields a linear and significant correlation for each concentration. PCR data quality is said to be good if the PCR amplification efficiency is close to $100 \%$ (Yuan et al., 2006).

At this time, many programs facilitate the designing of primers. Users can conveniently design primers by modifying the length of the primer, the length of the DNA amplification product, and the guanine-cytosine (GC) content according to the research needs. Moreover, these programs are integrated with the DNA sequence database, meaning that after the primer is designed, the specificity of the target DNA and any mismatches that may arise can be observed directly. Besides, they enable the estimation of whether the designed primers are attached to the DNA sequences of other species or specific to the target DNA. Primer specificity is essentially considered in the PCR technique; in other terms, specific primer design is crucial to the success of a PCR-based analytical method (Sudjadi, 2008).

One of the goals of this research is to obtain a specific primer from bovine mitochondrial DNA for DNA identification in real-time PCR. Bovine DNA in this research was obtained from Bos taurus, a species of cows originating in Europe. This group eventually spread to various parts of the world, including Indonesia. Since the raw material of gelatine mostly comes from Bos taurus, this research uses and focuses on this cow species.

\section{MATERIALS AND METHOD Materials}

The primer was designed with software hosted by the NCBI website and subsequently ordered from PT Genetika (Jakarta, Indonesia). Beef (Bos taurus) and pork (Sus scrofa) meat were purchased from the traditional markets in Yogyakarta. The species-specific primers were 
designed and tested with this software. The other solvents and chemical reagents were bought from E. Merck (Darmstadt, Germany).

The research instrument included real-time PCR CFX 96 (Biorad, USA), and the procedure was processed at LPPT-UGM.

\section{The designing phase of DNA specific primer}

The bovine DNA primer was designed using NCBI-Primer BLAST software by inputting the desired criteria data. The resultant primers were then confirmed for their specificity for Bos taurus.

\section{DNA isolation and subsequent purity test}

DNA isolation was carried out by grinding $200 \mathrm{mg}$ of each meat sample with a mortar and then inserting it into a $2 \mathrm{ml}$ microtube. A warm lysis buffer was added as much as $700 \mu \mathrm{L}$ to the microtube, and $10 \mu \mathrm{L}$ proteinase- $\mathrm{K}$ was added later. The mixture was homogenized with a vortex device, incubated in a water bath at $65^{\circ} \mathrm{C}$ for 2 hours, and then vortexed until the meat sample was destroyed. Phenol-KIAA solution with 1: 1 volume was added to the microtube. Afterward, the mixture Submitted: with a shaker for 30 minutes. The samples were centrifuged at a speed of 12,000 rpm for 5 minutes, producing two layers in each sample. The supernatant, the liquid at the top payer, was collected, placed in a new microtube, and then added with 2-propanol with a volume of 1: 1 . The mixture was incubated in the freezer for 15 hours then centrifuged again at a speed of 12,000 rpm for 5 minutes. Afterward, the DNA precipitated and was seen at the bottom of the microtube. The supernatant from centrifugation results was then discarded. A total of $500 \mu \mathrm{l}$ of $70 \%$ ethanol solution was added into the microtube and centrifuged at 12,000 rpm for 5 minutes. After centrifugation, the supernatant was completely removed and allowed to dry, so that DNA pellets could form at the bottom of the tube. The DNA pellets were dissolved in $100 \mu \mathrm{L}$ TE buffer, homogenized, and incubated at $50^{\circ} \mathrm{C}$. The isolated sample was then stored in the freezer (Olson, N. D., and Morrow, J. B., 2012).

The results of DNA isolation were analyzed for its purity by measuring the absorbance of $20 \mu \mathrm{L}$ DNA solution in $980 \mu \mathrm{L}$ sterile aqua at the wavelengths $(\lambda) 260 \mathrm{~nm}$ and $280 \mathrm{~nm}$. Meanwhile, the DNA concentration was calculated from the absorbance value at $\lambda 260 \mathrm{~nm}$ and multiplied by the dilution factor and the absorption constant $(50 \mu \mathrm{g} / \mathrm{mL})$.

\section{Real-Time PCR Analysis}

The real-time PCR analysis was performed using a reaction mixture $(20 \mu \mathrm{L})$ consisting of $10 \mu \mathrm{L}$ SYBR Green ${ }^{\circledR}$ universal PCR master mix, $1 \mu \mathrm{L}$ forward and reverse primer, $1 \mu \mathrm{L}$ DNA template (50 ng), and $7 \mu \mathrm{L}$ free nuclease water. The temperature was set at $95^{\circ} \mathrm{C}$ for 30 seconds, followed by 30 cycles at a temperature of $95^{\circ} \mathrm{C}$ for 5 seconds for the denaturation stage. The next step was the primer attachment. This procedure was performed at the optimized primer attachment temperature for 10 seconds and $72^{\circ} \mathrm{C}$ for another 10 seconds to create the advanced stage (extension). The melting curve was carried out at the temperature of $60-90^{\circ} \mathrm{C}$ with a slope of $0.5^{\circ} \mathrm{C} / 2$ seconds (Himawati, 2013).

\section{Optimization of annealing temperature}

The annealing temperature primer that had been designed for rat DNA was optimized at the temperature range of 52 to $62^{\circ} \mathrm{C}$ using real-time PCR (Bio-Rad, 2006).

\section{The specificity of primer}

The primer specificity was confirmed by amplifying $50 \mathrm{ng} / \mu \mathrm{L}$ DNA of beef, pig, and negative control (without DNA) called NTC (No Template Control). 


\section{Repeatability test}

The repeatability of the method was assessed based on the coefficient of variation (CV). This value was obtained from 6-time replication of the amplification of isolated DNA from fresh beef at the concentration of $50 \mathrm{ng} / \mu \mathrm{L}$.

\section{Data Analysis}

The real-time PCR results were analyzed using a standard curve created by comparing $\mathrm{Cq}$ values (Quantification circle) with the log-transformed DNA concentration. The real-time PCR efficiency $(\mathrm{E})$ was calculated using the formula: $\mathrm{E}=(10(-1 /$ slope $)-1) \times 100(\mathrm{Bio}-\mathrm{Rad}, 2006)$.

\section{RESULTS AND DISCUSSION}

Designing primer is the initial stage of real-time PCR analysis. In this study, the primer design aimed to obtain a specific primer arrangement of bovine mitochondrial DNA (Bos taurus). Sudjadi (2008) states that the determining factor of the success of PCR is the use of primers that are specific to the target or, in other words, specific primers are vital to achieving an optimal result. Mitochondrial DNA can be targeted for genes or molds in the PCR process. It has many advantages, including the incorporation of mitochondrial DNA - which is inherently more stable under various conditions during the production process. A cell can contain thousands of copies of mitochondrial DNA, while the number of samples required in PCR analysis is small. With these advantages, PCR analysis using mitochondrial DNA as a target is, therefore, a relatively cheaper, more straightforward, and more sensitive method (Nuraini et al., 2012).

Mitochondrial DNA as a target has been widely used in research employing both conventional PCR and real-time PCR. Aida (2005), Rahman (2014), and Camma (2012) have developed PCR methods with mitochondrial DNA as a target sequence. Mohamad et al. (2013) suggest that the template used in real time-PCR, either mitochondrial DNA or nuclear DNA, significantly affects the sensitivity and specificity of the analysis method.

The PCR amplification results were detected with SYBR Green. SYBR Green is a fluorescencebinding agent with double-stranded DNA that can be detected at $\lambda$ exitation $=498 \mathrm{~nm}$ and $\lambda$ emission= $522 \mathrm{~nm}$, and the intensity of fluorescence that arises is read by the detector tool. Compared to other detectors, SYBR Green can be universally used in various prints because of its non-specific nature that it can bind to any double-stranded DNA, and it is cheaper, simpler to use, and more stable at elevated temperatures. Also, it does not interfere with DNA Polymerase (McPherson and Simon, 2006).

The primer was designed using the Primer-BLAST software available on the NCBI website. The organism of target used in the primer design for this study was Bos taurus, in particular, the cytochrome b gene region with the GenBank code AF492351. The primer candidates were obtained from the primer designs produced by BLAST software for other organisms. The in silico preliminary testing of the primer design yielded a pair of primers that were later used in this study, as shown in Table I.

Table I. The primer design of the Cytochrome-B region of Bos taurus

\begin{tabular}{llllll}
\hline Primer & & Length & Tm & \%GC & $\begin{array}{l}\text { Product } \\
\text { Length }\end{array}$ \\
\hline Forward & CTACTGACACTCACATGAATTGG & 23 & 57.21 & 43.48 & $99 \mathrm{bp}$ \\
Reverse & CACTAGGATGAGGAGAAAGTATAGG & 25 & 57.44 & 44.00 & 9 \\
\hline
\end{tabular}

Table II shows the results of the quantitative analysis, namely the A260/A280 ratio, of DNA isolates using a spectrophotometer. Clark (2005) affirms that pure DNA has a ratio of 1.8. Accordingly, ratio $<1.8$ indicates protein contamination, while ratio $>1.8$ represents RNA contamination. The quantitative analysis revealed that the isolation included imperfect washing, 
meaning that the DNA obtained was not pure. Codex Alimentarius Commission (2010) explains that high DNA purity allows optimal amplification that affects the validity of a PCR method.

Table II. The results of quantitative analysis and purity test of DNA meat isolates by spectrophotometry

\begin{tabular}{lcc}
\hline Types of Meat & Concentrations $(\boldsymbol{\mu g} / \mathbf{m L})$ & $\mathbf{A}_{\mathbf{2 6 0}} / \mathbf{A}_{\mathbf{2 8 0}}$ Ratio \\
\hline Porcine & 1952.68 & 2.00 \\
Bovine & 1897.80 & 1.50 \\
\hline
\end{tabular}

A primer is designed with a theoretical melting temperature $(\mathrm{Tm})$ based on the GC content of the primer. Muladno (2010) states that the primer attachment temperature is usually in the range of 50$60^{\circ} \mathrm{C}$ or approximately $5^{\circ} \mathrm{C}$ below the Tm of the design primers. However, temperature optimization is a necessary element to achieve optimal PCR results that are specific to bovine DNA. In this study, the temperature was optimized using the bovine and porcine DNA targets from a range of primer attachment temperature, which was $53.6-59.0^{\circ} \mathrm{C}$, based on the estimated $\mathrm{Tm}$ of the designed primers (Table III).

Table III. The optimized annealing temperatures of primers from bovine DNA

\begin{tabular}{cccc} 
Optimized Temperature & \multicolumn{1}{l}{ Cq } & Melt Temperature & Peak Height \\
\hline 58.7 & 26.03 & 77.00 & 666.82 \\
59.0 & 26.01 & 77.00 & 603.13 \\
53.6 & 26.03 & 77.00 & 635.55 \\
55.0 & 26.11 & 77.00 & 608.09 \\
\hline
\end{tabular}

The results of the optimization of annealing temperature are presented in Figure 1. Based on the figures, the exact annealing temperature used in the PCR real-time test protocol is $58.7^{\circ} \mathrm{C}$. At this temperature, the maximum amplification results and the highest melting temperature among other optimization temperatures are achieved.

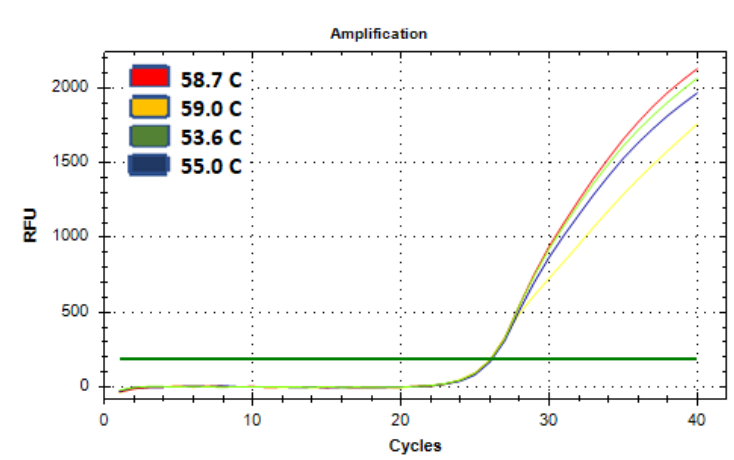

(A)

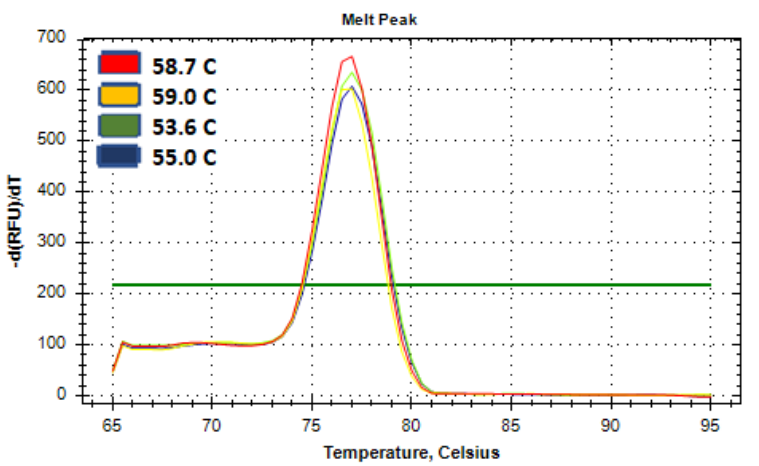

(B)

Figure 1. The results of the amplification of bovine DNA and the optimization of annealing temperature of the designed primers (A) Cycles (B) Melting temperature

PCR strongly depends on the specificity of primer because a specific primer design can lead to the success of any PCR-based analytical methods (Sudjadi, 2008). Specific primers are primers that can be used to amplify the target DNA, rather than amplifying the DNA of other species as universal primers do. In this study, the specificity testing was carried out only on the porcine DNA. This method is a necessary step to initiate the test on samples of gelatin because the available gelatin on the market mostly comes from pigs and cows. The negative control, NTC (no DNA content), was also subjected to a specificity test. Based on the results of the specificity test (Figure 2), it appears that only bovine 
DNA is amplified, whereas NTC and porcine DNA are not. This result indicates that the primer used in this study is specific.

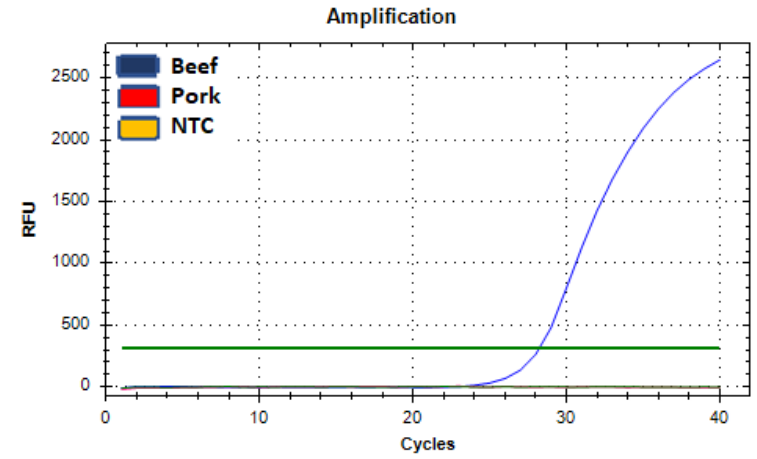

(A)

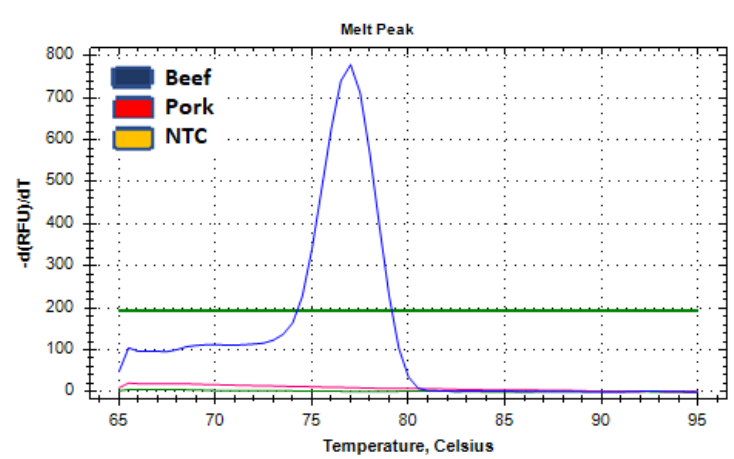

(B)

Figure 2. The results of the amplification (A) of the designed primers, with Cq: 28.22 and (B) Tm: 77.00

The test of method repeatability was carried out by observing the amplification results of the amplification of rat meatball samples with a concentration of $100 \%$ and the amplification products of rat meat that was replicated six times to see the consistency of the real-time PCR results (Figure 3 and Table IV). The Relative Standard Deviation (RSD) or CV of Cq is the basis for making decisions of whether or not the method is consistent. Codex Alimentarius Commission (2010) sets the acceptable coefficient of variation $(\mathrm{CV})$ for a repeatable PCR analytical method at $25 \%$. The $\mathrm{CV}$ of $\mathrm{Cq}$ from the amplification of bovine DNA with a concentration of $50 \mathrm{ng} / \mu \mathrm{L}$ was $1.91 \%$, while the $\mathrm{CV}$ of $\mathrm{Cq}$ from rat meat amplification was $1.01 \%$. These results indicate that the method meets the repeatability requirements.

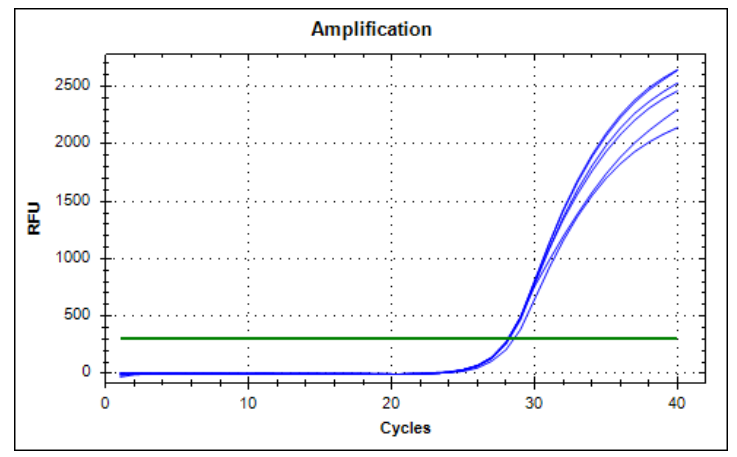

(A)

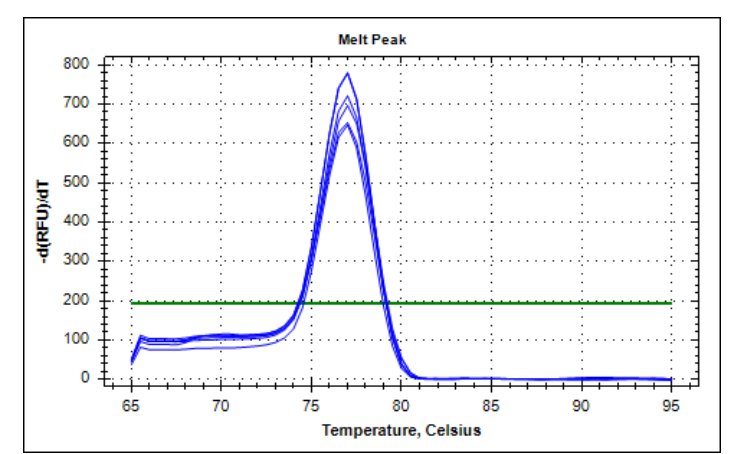

(B)

Figure 3. The repeatability test results of DNA amplification from beef isolates with the DNA concentration of $50 \mathrm{ng} / \mu \mathrm{L}$ (A) Cycles (B) Melting Curve 
Table IV. The repeatability of PCR analytical method for bovine DNA

\begin{tabular}{ccccccc}
\hline Sample & Cq & Tm & $\begin{array}{c}\text { Peak } \\
\text { Height }\end{array}$ & $\begin{array}{c}\text { average } \\
\text { Cq }\end{array}$ & SD & $\begin{array}{c}\text { CV } \\
(\%)\end{array}$ \\
\hline & 28.59 & 77.00 & 647.04 & & & \\
Bovine DNA & 28.22 & 77.00 & 778.70 & & & \\
concentration 50 & 28.19 & 77.00 & 780.05 & 28.27 & 0.1621 & 0.57 \\
$(\mathrm{ng} / \mu \mathrm{L})$ & 28.26 & 77.00 & 721.29 & & & \\
& 28.17 & 77.00 & 696.51 & & & \\
\hline
\end{tabular}

Linear regression equations were also obtained from the standard curve of amplification reaction to DNA isolates from beef (Figures 4 and 5), with $\mathrm{R} 2$ values $=0.966$, slope $=-2.059$, and $\mathrm{y}$-intercept $=$ 28.830 , meaning that the curves meet the linearity criteria.

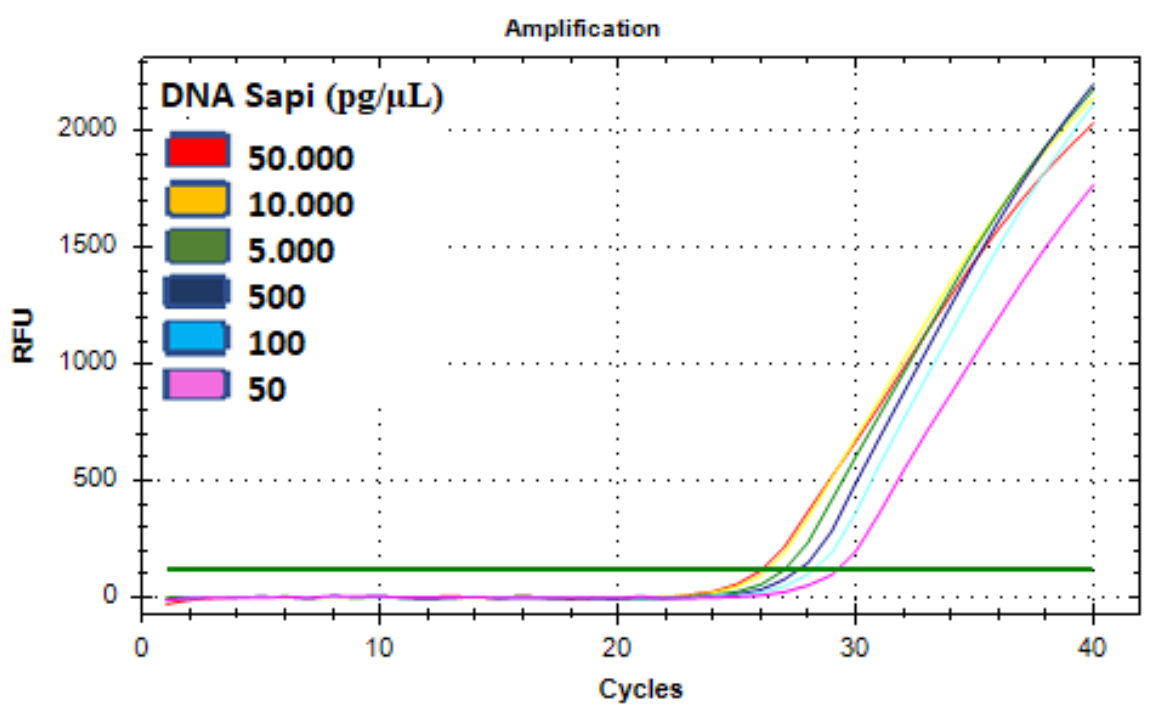

Figure 4. The results of bovine DNA amplification at various concentrations

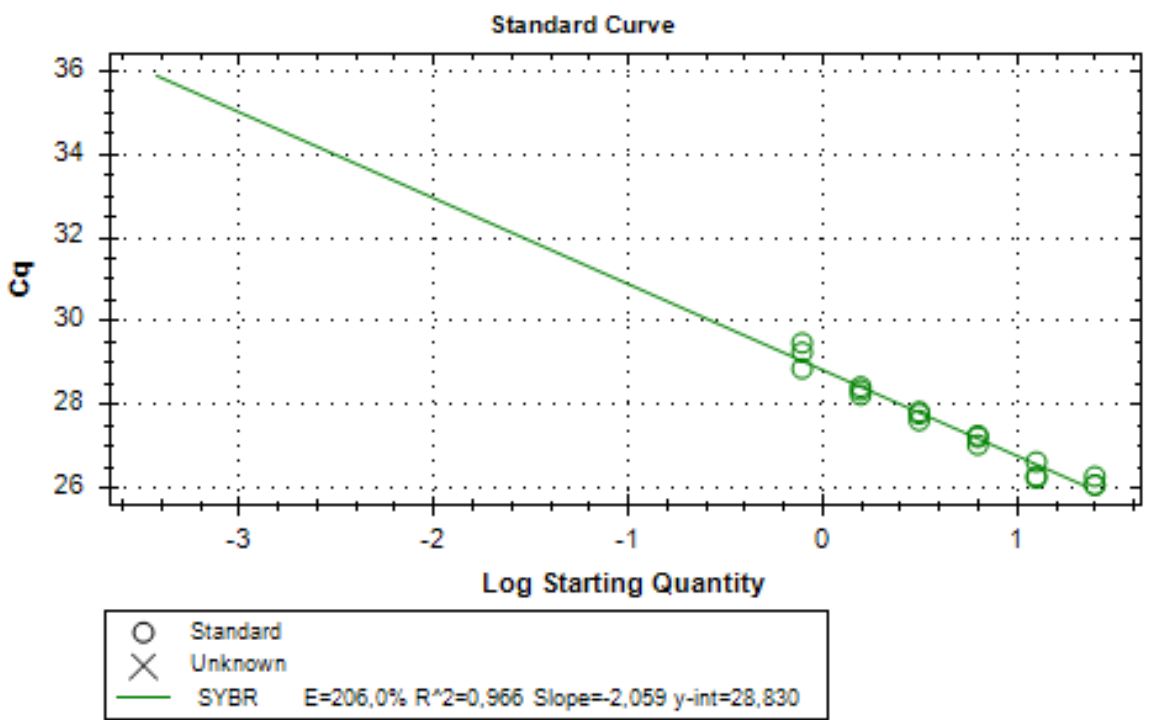

Figure 5. The standard curves of bovine DNA amplification at various concentrations 
The standard curve between log-transformed bovine DNA concentration and Cq (Figure 5) shows an efficiency (E) of 206.0\%. This percentage indicates imperfect results due to high-efficiency values. Bio-Rad (2006) states that the results of PCR amplification are considered as good or acceptable if the efficiency value is close to $100 \%(90-105 \%)$ and the value of R2 is $>0.980$. If amplification efficiency values are higher than $100 \%$, the thermocycling conditions and the reactions occurring in PCR components are less than optimal (Life Technologies, 2012). Efficiency values can be influenced by several factors, namely the presence of inhibitors in the master mix PCR, the purity of the reagents used, inconsistencies in the small volume piping process - which results in low accuracy, and the testing ability that depends on the primer specificity and target sequence length of the printed DNA (Svec et al., 2015; Muhammed et al., 2015). Extremely high efficiency indicates that the target DNA duplicated in each cycle is disturbed by the presence of an inhibitor during the reaction, whereas too small efficiency values represent imperfect primer attachment. Both cases result in less exponential template amplification in each cycle.

\section{CONCLUSION}

Specific primers 5 '- CTACTGACACACACACGAGAATTGG - 3' (forward) and 5 'CACTAGGATGAGGAGAAAGTATAGG - 3' (reverse) from the cytochrome-b region of bovine mitochondrial DNA (Bos taurus) can be used specifically to distinguish bovine DNA from porcine DNA (Sus scrofa) using real-time PCR method with an optimum temperature of $58.7^{\circ} \mathrm{C}$ for primers attachment. Therefore, these primers can be used for analyzing the halal authentication of gelatin.

\section{ACKNOWLEDMENT}

The author wishes to thank PDD Ristekdikti for the support in this research.

\section{REFERENCES}

Aida, A.A., Man, Y.B.C., Wong, C.M.V.L., Raha, A.R., and Son, R., 2005, Analysis of raw meats and fats of pigs using polymerase chain reaction for Halal authentication. Meat Science, 69: 47 - 52.

Bio-Rad., 2006. Real-Time PCR Application Guide, Bio-Rad Laboratories, Inc, USA.

Cammà, C., Domenico, M.D., and Monaco, F., 2012, Development and validation of fast Real-Time PCR assays for species identification in raw and cooked meat mixtures. Food Control, 23: $400-$ 404.

Clark, D.P., 2005, Nucleic acids: isolation, purification, detection and hybridization, Molecular Biology: Understanding the Genetic Revolution. Elsevier Academic Press, London. 567-598.

Codex Alimentarius Commission, 2010, CAC/GL 74: Codex Guidelines on Performance Criteria and Validation of Methods for Detection, Identification, and Quantification of Specific DNA Sequences and Specific Proteins In Foods.

Himawati, A., 2013, Analisis Campuran Daging Babi dan Sapi dalam Bakso dengan Metode Spektrofotometri Fourier Transform Infrared dan Real-Time Polymerase Chain Reaction. Universitas Gadjah Mada, Yogyakarta.

Iwobi, I.H., and Ulrich, B., 2012, The Application of PCR-Based Methods in Food Control Agencies A Review, Dr. Patricia Hernandez-Rodriguez (Ed.), Polymerase Chain Reaction. InTech, 566.

Life Technologies, 2012, Real-Time PCR Handbook -Gene Quantification. Life Technologies Corporation.

Martin, M., García, T., Violeta, F., María, R., Nicolette, P., Hernández, P.E., et al., 2009, SYBRGreen real-time PCR approach for the detection and quantification of pig DNA in feedstuffs. Meat Science, 82: $252-259$.

McPherson and Simon., 2006, PCR, second. Ed. Taylor and Francis Group.

Mohamad, N.A., El Sheikha, A.F., Mustafa, S., and Mokhtar, N.F.K., 2013, Comparison of gene nature used in real-time PCR for porcine identification and quantification: A review. Food Research International, 50: 330-338. 
Muhammed, M.A., Bindu, B.S.C., Jini, R., Prashanth, K.V.H., and Bhaskar, N., 2015, Evaluation of different DNA extraction methods for the detection of adulteration in raw and processed meat through polymerase chain reaction-restriction fragment length polymorphism (PCR-RFLP). Journal of Food Science Technology, 52: 514 - 520.

Muladno, 2010. Teknologi Rekayasa Genetika. IPB Press, Bogor.

Nuraini, H., A. Primasari, E. Andreas, and C. Sumantri., 2012, The Use of Cytochrome b Gene as a Specific Marker of the Rat Meat (Rattus norvegicus) on Meat and Meat Products. Media Peternakan, 15 - 20.

Olson, N. D., and Morrow, J. B., 2012, DNA extract characterization process for microbial detection methods development and validation, BMC Research Notes, 5, 668.

Rahman, M.M., Ali, M.E., Hamid, S.B.A., Mustafa, S., Hashim, U., and Hanapi, U.K., 2014, Polymerase chain reaction assay targeting cytochrome $\mathrm{b}$ gene for the detection of dog meat adulteration in meatball formulation. Meat Science, 97: $404-409$.

Sambrook, J., Fritsch, E. F., and Maniatis, T. A., 1989, Molecular Cloning: A Laboratory Manual. $2^{\text {nd }}$, Cold Spring Harbor Laboratory Press, Cold Spring Harbor, NY, USA., 397.

Soares, S., Amaral, J.S., Oliveira, M.B.P.P., and Mafra, I., 2013, An SYBR Green real-time PCR assay to detect and quantify pork meat in processed poultry meat products. Meat Science, 94: $115-$ 120.

Sudjadi., 2008, Bioteknologi Kesehatan. Kanisius, Yogyakarta.

Svec, D., A. Tichopad, V. Novosadova, M.W. Pfaffl and M. Kubista., 2015, How good is a PCR efficiency estimate: Recommendations for precise and robust qPCR efficiency assessments. Biomol. Detection Quantification, 3: 9-16.

Taufiq, R., 2014, Analisis Kontaminasi DNA Babi pada Abon dengan Primer Mitokondria D-Loop22 menggunakan Metode Real-Time Polymerase Chain Reaction. Universitas Gadjah Mada, Yogyakarta.

Yuan, J.S., Reed, A., Chen, F., and C Neal Stewart Jr, 2006, Statistical analysis of real-time PCR data. BMC Bioinformatics, 7: Bio-Rad, 2006. Real-Time PCR Application Guide. Bio-Rad Laboratories, Inc, USA. 
